\title{
Impulses from Charlotte Selver's Sensory Awareness in the Work of Lenore Tawney
}

"I learned to feel the ground below my feet, and to pay attention to each breath, and to every sensation," noted the American fiber artist Lenore Tawney about the changes in her perception of herself and her body brought about by the Sensory Awareness work of Charlotte Selver. Around 1959, a development from figurative to abstract motifs made itself ever more evident in Tawney's artistic production as the result of an experimental application of her employed weaving techniques that increasingly integrated space in an installative manner. This culminated around 1961/62 with her use of the gauze technique in the "Woven Forms" she would show at her eponymous 1963 exhibition (Fig. 1) where the three-dimensionality of the textiles as well as distinct contrasts between invisible and transparent sections in the fabrics were exposed. The weavings were made at Coenties Slip on the tip of Lower Manhattan where Tawney's studio neighbors were Jack Youngerman, Robert Indiana, Agnes Martin and Ellsworth Kelly. The latter characterized Tawney's large-format textile pieces that hung freely in the space as pioneering works for the evolution of installation art and the dealings with space and material in the art of the nineteen sixties. ${ }^{2}$

Afraid of going blind, Tawney began attending workshops and individual sessions with Selver in the late nineteen fifties. ${ }^{3}$ After 1959, and even more so around 1962, it is increasingly apparent that Tawney's experiences with Sensory Awareness flowed into her weavings, especially as she allowed a moment of letting something happen within the otherwise highly systematized specifications of the weaving process. In a letter to Selver, she wrote: "This is what I meant last spring when

1 Lenore Tawney, “Autobiography of a Cloud," p. 16, transcript, Lenore G. Tawney Foundation (hereafter cited as LGTF).

2 The author's interview with Ann Wilson, who likewise lived at Coenties Slip, in Taos, 24.3.2012.
3 In an unpublished German-English interview in which Selver is looking through her diaries with her co-worker Stefan Laeng, she notes: "I was there for Lenore Tawney, [who was afraid of going blind. She did go blind when she was older but ... she could still see the tiniest of threads.]" The German passage in the original text is translated in [...]), Selver-Archiv Stefan Laeng (hereafter cited as SASL). 


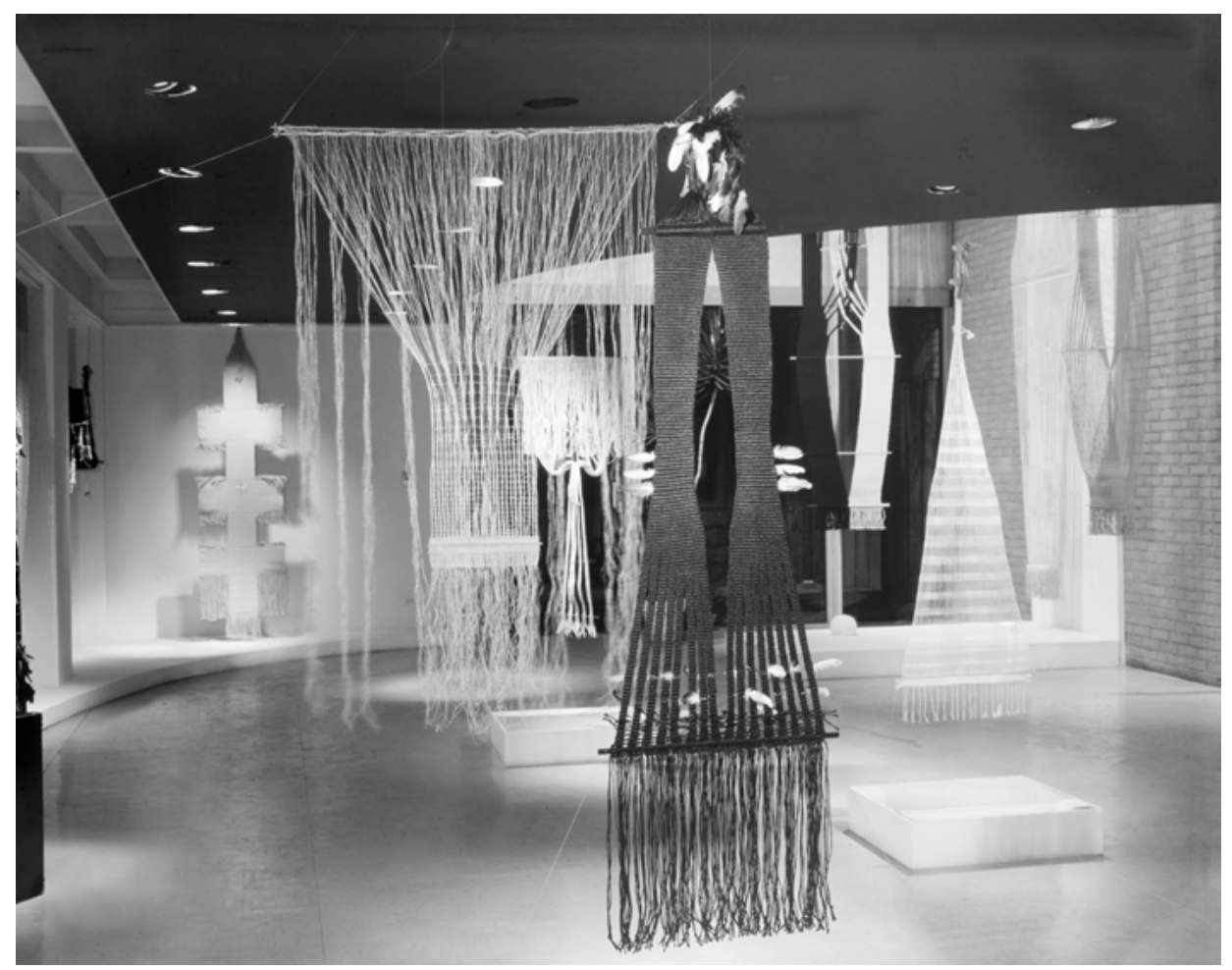


I wrote you - Life is more important than work (my work) and out of life comes the work. Before, I had been saying - my life is my work. It seems very important to me - this realization [...]. The breathing sessions I found a most profound experience."4 In my opinion, the forms discernible in these new works made during and after her first large solo exhibition at the Staten Island Museum in 1961 - about which the art critic Eleanor Munro wrote in 1979 that "she launched herself into the production of images of a wholly new order" 5 - were concretely inspired by the changes in her perception of her body and her Self. Not only the stimulating incentives that the exhibition gave Tawney - which Munro references - led to the new anthropomorphic woven forms from 1962 but also - according to my thesis - that Tawney's experience with Selver's work with the body provided new strong stimuli. Of importance in this process is especially the sensitization for the sensual perception beyond conventional subjectivation and the concentration on the breathing in keeping with the body theory on which this method is founded.

Tawney met Selver in 1959 and began an intensive phase of working with her: "Finally, I was going four days a week. It was a wonderful experience. I went for years; and I went with them to Monhegan. I went every summer, for the whole summer."' This period of concentrated practice has astonishingly gone largely unnoticed in the literature on Tawney. Only mentioned in a biographical context until now, ${ }^{7}$ the following analysis will explore this aspect in greater detail, namely that the changed perception of the body and world as well as the sensitization for her own breathing had a fundamental impact on Tawney's work as an artist. Accordingly, an access to the interpretation of her works will be identified in precisely this perception of the body. The objective is to demonstrate that the Sensory Awareness exercises not only had an impact on her work as regards motif but also as an epistemological form and method to the extent that they operate on a level of perception where rational, cognitive perspectives no longer dominate over other manners of experience but rather on which various forms of subjectivity

4 Tawney, cited from "Excerpts from Letters to Charlotte Selver from Lenore Tawney 1959-1964 x 5/6/03," transcript, LGTF.

5 Eleanor Munro, Originals. American Women Artists, New York 2000 [1979], p. 329.

6 Tawney in an interview with Mary Alice Roche in Tawney's New York studio, 17.7.1990, in SASL, pp. 1-7, here: p. 3. Selver also visited Tawney in her studio. - On the dating: Glen Adamson mentions that Tawney took part in Selver's workshops on Mohegan Island in Maine together with her friend from the nineteen sixties and seventies, the fiber artist Ted Hallman; he dates the piece "at least as early as
1964." See Glen Adamson, "Seeker. 1970 to 1980," in: Lenore Tawney. Mirror of the Universe, exh. cat. John Michael Kohler Arts Center, Sheboygan, Wisconsin, Chicago/London 2020, pp. 176-195, here: p. 179. Aside from a joint 1960 trip to Honolulu mentioned in Selver's diary and her comments on it in Stefan Laeng's interview with her, Tawney's letters to Selver document their acquaintanceship after 1959, which the artist again confirmed in the 1990 interview with Roche (note 6), p. 1. 7 Adamson 2020 (note 6), p. 179. 
become tangible in their sensual dimension. This sensual and physical affixation through Sensory Awareness unites with concepts from Amerindian and East Asiatic cultures received by Tawney at that time. I understand these different knowledge formations not to be in competition with each other ${ }^{8}$ but rather as reinforcing each other, as an "as well as." 9

\section{Sensory Awareness}

The German-Jewish physical and behavioral educator Charlotte Selver fled Nazi Germany for the United States in 1938. It was there that she developed the Sensory Awareness method, for which the perception of one's own breath is of fundamental significance. The exercises drew from concepts and practices that Selver learned from the physical education teacher Elsa Gindler in Berlin during the nineteen twenties; her work would form the foundation for Selver's own approach. Further influence was provided by the musician and researcher in the field of human learning and creativity Heinrich Jacoby, a teacher in the Bauhaus circle she met in Hellerau..$^{10}$ For him, it was of crucial importance for "humankind's general observation and communication skills" that a sense for "letting things arise" and "letting things happen" be enabled instead of active, haphazard action. ${ }^{11}$ These are likewise impulses that Selver adopted as core elements in her work with breathing. ${ }^{12}$ Emphasis is placed here on the fact that her approach is not oriented on concrete goals. Instead, as she writes: "Since we do not seek a verbal or in any way definitive answer, this is a study without a certifiable achievement and without end. Its only interest is the essential interest in living processes themselves." 13

The psychologist Fritz Perls was one of her pupils in the nineteen forties and carried out intensive studies with her; he would later employ numerous elements of their work in his Gestalt therapy. Selver also met Erich Fromm in 1944, whose support probably enabled her to offer classes at the New School of Social Research. Fromm made use of her approaches in his 1956 social-psychological book The Art of Loving. ${ }^{14}$

8 See Boaventura de Sousa Santos, The End of the Cognitive Empire. The Coming of Age of Epistemologies of the South, Durham 2018.

9 See Mona Schieren, Agnes Martin. Transkulturelle Übersetzung, Munich 2016, p. 383 and Zairong Xiang, "Transdualism. Toward a Materio-Discursive Embodiment," in: Transgender Studies Quarterly 5 (3), August 2018, pp. 425-442, available at: DOI 10.1215/23289252-6900795 (last accessed: 28.9.2020): Instead of a "below either/ or logic" (p. 426) I examine rather an "either [...] and" (p. 428) constellation.
10 See Charlotte Selver, "Vorwort (Ein Wort von Charlotte Selver)," in: Charles V. W. Brooks (ed.), Erleben durch die Sinne. Sensory Awareness (=Innovative Psychotherapie und Humanwissenschaften 7), German trans. by Charlotte Selver, ed. Hilarion Petzold, Paderborn 1979, p. 9. (Selver's preface is not printed in the English version.)

11 Trans. from Brooks 1979 (note 10), p. 217.

12 For an extensive bibliography, see ibd., p. 219.

13 See Charles V. W. Brooks, Sensory Awareness. The Rediscovery of Experiencing through Workshops with Charlotte Selver, New York ${ }^{3} 1986$, pp. $19 f$.

14 Erich Fromm, The Art of Loving, New York 1956, p. 113. 
In 1956 at the latest, Selver met the philosopher and Orientalist Alan Watts, who exclaimed about her method while working with her, "But this is living Zen."15

In her text "On Breathing," Selver emphasizes the unintentional exploration of breathing. ${ }^{16}$ She is not concerned with a breathing technique like the Vedantic Pranayama, for example, in which breathing is to be especially trained or controlled. She comprehends breathing instead as the key to self-perception "as it represents our most regular and intimate relationship to our environment; and its uninhibited functioning involves more of our flexibility and musculature than any other organismic activity." 17 In moments of hesitancy, Selver writes, one should perceive one's own breath and not breathe - but also not hold one's breath - until finally the impulse to breath arises "by itself":

\begin{abstract}
"The response in breathing, if we are not holding it back or are not too uninterested or habitual inside so that it can't happen, will constantly allow the necessary supply of energy for what we are doing. We don't have to say, 'Breathe!' For heaven's sake, forget that! It comes by itself, spontaneously - if we allow it. Therefore, it is the allowing - the possibility of becoming more permissive - that we want to explore."18
\end{abstract}

Numerous biographical moments can be identified that can be associated with the innovations in Tawney's working method. These include the move to New York, where she lived and worked on the tip of Lower Manhattan, her dealings with the artistic stimulus at Coenties Slip as well as with philosophical writings, Amerindian weaving and the learning of new weaving techniques. ${ }^{19}$ The effects that the impulses from Selver's practice of corporeal affixation and of "allowing" (also) had on her artistic work probably strengthened Tawney's resolve to take new and innovative paths with these newly learned techniques. ${ }^{20}$ While artistic processes are in any case often less a process of planned, cognitively guided actions than rather letting something come about with the aid of chance, weaving, with its systematic procedures such as the organization of warp and weft requires a high degree of planning involving

15 Alan Watts, cited from Brooks 1986 (note 13), p. 232.

16 Charlotte Selver, "On Breathing" (1971), cited from Charlotte Selver, Collected Writings Volume I: Sensory Awareness and Our Attitude Toward Life (=Sensory Awareness Foundation, Bulletin 151 (1)), Mill Valley, California 1999, pp. 42-45, here: p. 42.

17 Brooks 1986 (note 13), p. 238.

18 Selver 1999 (note 16), p. 43.

19 In 1946/47, Tawney studied sculpture with Alexander Archipenko and László Moholy-Nagy at the Institute of Design in Chicago and became acquainted with weaving under Marli Ehrman. Only later, however, in 1954, would she discover this as her medium. She continued exploring weaving on trips to South America and studied in 1954 with the Finnish weaver Martta Taipale at the Penland School of Crafts. She began working in a motival-figurative manner here, the works themselves were essentially two-dimensional in nature. In 1961, she learned the gauze technique from Lili Blumenau.

20 Looking back in 1965, she also alluded to these changes in her working method in a letter to her art dealer Marna Johnson; see Tawney to Johnson, 15.4.1965, LGTF. 
the body in the work in a special way to the extent that the structure of the textile designed in advance directly affects the motoric incorporation of the body and consequently of breathing as well.

\section{Woven Breathing Bodies}

One noticeable aspect of the innovative woven sculptures from 1961/62 like The Bride (Fig. 2), The Queen or The King ${ }^{21}$ that were shown at the 1963 "Woven Forms" exhibition (see Fig. 1) as well as several further works such as The Fountain of Word and Water (1963) (see Fig. 3) is the fact that they all feature elliptical openings in the central part of the textile. Tawney says about these works: "It's an inner, interior landscape that I'm doing, metaphors for interior states." 22 Accordingly, if one reads the titles as allusions to human figures, the upper third of each piece corresponds to the chest. Some of the figures have very large elliptical recesses whose structures can be associated with the rib cage or the heart and stomach area, respectively. The outer contour in the upper sections of these hangings is made with the aid of a procedure developed by Tawney ${ }^{23}$ that enables curved weaving edges, each one wider while narrowing towards the bottom into a 'waist' or a 'diaphragm,' only to then transition into a wider section - perhaps a 'pelvis'? - that in turn is woven differently and finally narrows minimally again at the bottom, ${ }^{24}$ or widens again at this point, respectively, in the case of The King. ${ }^{25}$ In her piece The Bride, the area around the rib cage is structured by means of a few slits; as to the rest, warp and weft form a firm thick textile. ${ }^{26}$ At the height of the heart or solar plexus, fine feathers have been integrated into the central slit-like opening. Tawney herself associates the frequent use of feathers in some of her other woven forms as well with breathing as it is understood in Amerindian traditions: "To an Indian, the downy white feather is very close to life itself. 'The

21 At Tawney's request, her friend Agnes Martin gave the titles to these pieces for a 1962/63 exhibition and explicitly selected gender-specific designations referencing the human form. It can be assumed that she chose the titles based on conversations with Tawney. In any case, she kept these titles and later even selected new ones from the corresponding word fields for long narrow woven forms.

22 Tawney on Dark River, cited from Ann Wilson, "Lenore Tawney. Reflections on a State of Being," 15 numbered manuscript pages with unnumbered appendix, LGTF, unpaged.

23 She made use of "a special reed, so that I could make them go out and in," Tawney, cited from Jean d'Autilia Lenore Tawney. A Personal World, exh. cat. Brookfield Craft Center, Brookfield 1978, unpaged.
24 The titles of the works more or less demand to be considered from a gender-specific perspective. Tawney's view of the gender aspect might also have been influenced by Jungian archetypes. An analysis of this dimension would lead us too far afield and must remain a topic for future consideration.

25 As opposed to the woven forms with female titles, The King I, designated a male figure by means of Agnes Martin's title, assumes a broad stance and there are only a few connections between the black and white sections of the textile.

26 See Florica Zaharia, "Technical Analysis: The Bride," exh. cat. Chicago/London 2020 (note 6), p. 170. 

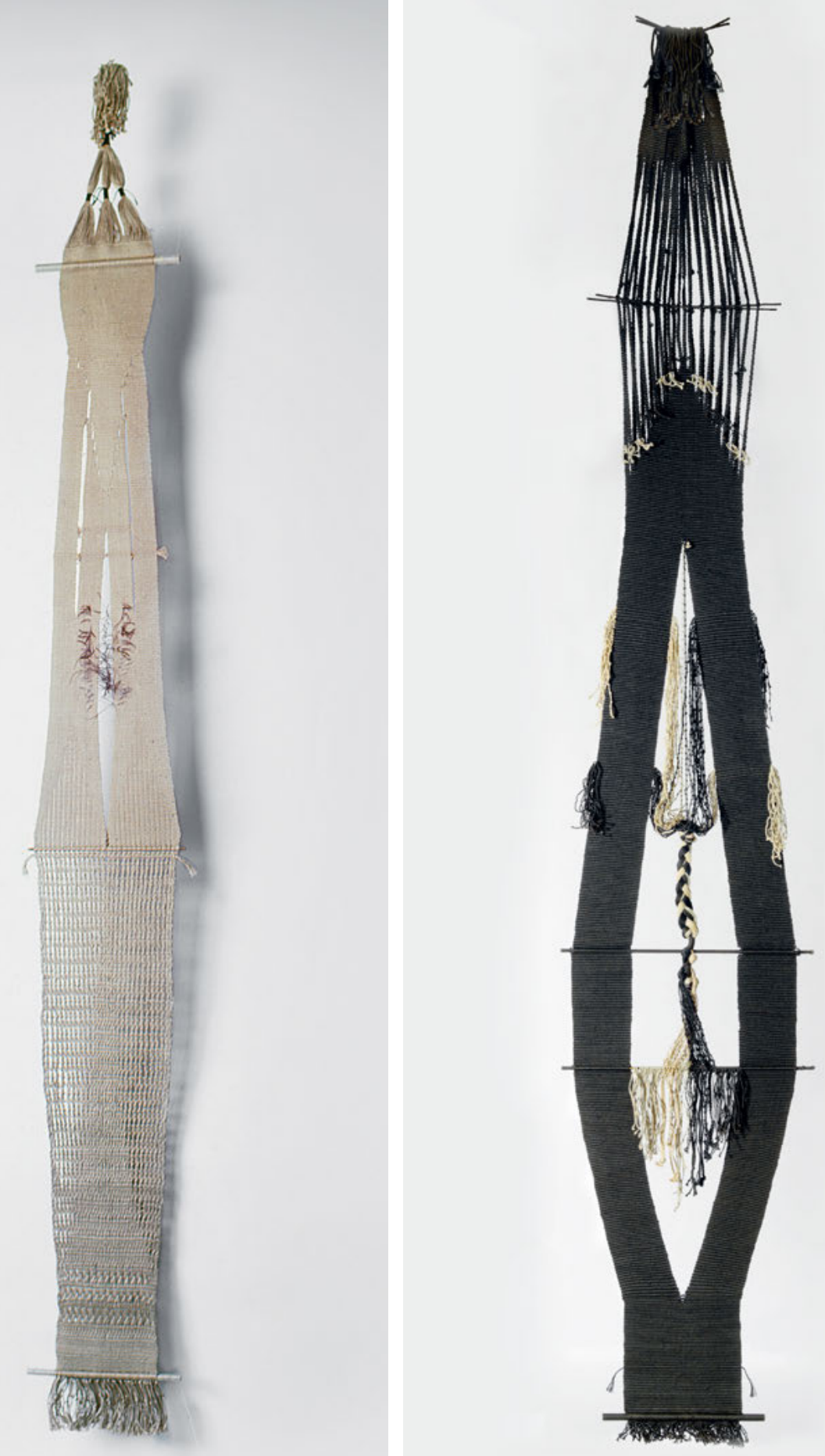

Fig. 2: Lenore Tawney, The Bride, linen, 1962, $350 \times 33 \mathrm{~cm}$
Fig. 3: Lenore Tawney, The Fountain (also known as The Fountain of Word and Water), linen, 1963, $411 \times 7 \times 15 \mathrm{~cm}$ 
feather is the pictorial representation of the breath' and 'breath is the symbol of life."”27

\section{Textile Fabric - Body Tissue}

In keeping with the analogy to body tissue suggested by Tawney's "interior landscapes," ${ }^{28}$ a connection can be established to the warp as the foundation of the weaving process that must exhibit a certain tension. The weft, on the other hand, is threaded through the warp, forming concentrations and loopings, for example, thus creating the diverse textures of the fabric. This can be translated to anatomically hard and soft parts of the body, respectively, that are moreover held tight or slackened through tension and contraction and can openly form a resonance with the impulses of their surroundings. The different woven fabrics are connected to each other like fasciae, while it is the middle, mostly elliptical opening of the central section that constitutes the woven forms, as is particularly evident in her piece The Innocent from $1962 .{ }^{29}$

In the context of the "belly" at the center of the body for which Brooks makes use of the Japanese concept of hara, Selver speaks in workshops about long closed "tissues" that "awaken" and become activated by breathing: "And now, through the gentle workings of breathing, it may be that we sense back and belly changing together. [...] We begin to experience ourselves as a single organism, where everywhere are needs and everywhere faculties, where numberless interconnections permit adjustments as the needs are felt" ${ }^{30}$ Accordingly, the central middle opening of The Fountain of Word and Water (1963), from which loose ends of threads 'gush', can be seen as the source of hara (Fig. 3).

Breath, however, extends beyond the mere affixation of tissue as it subverts the Western differentiation of physiological and psychological processes, the assumed division of which in any case Selver believes to be of "cultural origins without any biological validity." 11 Breath connects environment and organism in the metabolism, and it is precisely this reciprocal entanglement of the organism with its constituting and affixing environment that is visualized by Peruvian gauze weaving. ${ }^{32}$

27 Tawney, cited from Jean d'Autilia 1978 (note 23), unpaged.

28 Tawney, cited from Wilson (note 22), unpaged.

29 It is visible on the right side of the exhibition view (Fig. 1).

30 Brooks 1986 (note 13), p. 53.
31 Trans. from Brooks 1979 (note 10), pp. 17f.; see also Rolf Elberfeld, "Ästhetik des Atems," in: Studi di estetica, anno XLVI 5 (1), 2018, pp. 181-193, here: p. 182.

32 The weaving process Tawney learned from Blumenau works with loopings of individual groups of warp threads among themselves and through the weft threads so that warp and weft are not only linked in pairs but loop each other reciprocally, thus making it possible to form different connections and open areas. 


\section{Work in Progress: Weaving and Breathing}

Tawney describes the genesis of the woven forms as a process of breathing in and breathing out: "Those woven forms were inspirational. They came out of that desire to make things reach up - also out and up. They went out and it was like breathing in, and they came in at the top like breathing out. I would always think of them as inspiration and aspiration." 33 These artworks can consequentially be read as visual protocols of body perceptions woven by Tawney in the process of breathing in and out. The interpretation of the artifacts as maps of physical and emotional processes that closely tie the act of breathing to artistic formation can moreover be associated with conceptions of textiles in Amerindian contexts. As I have discussed elsewhere, Tawney made an intense study of East Asiatic and Amerindian ontologies, traveled to Mexico, North Africa, the Levant, Hawaii, Bolivia and Peru where she learned about local weaving techniques. ${ }^{34}$ Her method of appropriation can be comprehended as a kind of dialectical primitivism ${ }^{35}$ and as a contribution to a critical modernism discourse ${ }^{36}$ that not only provides for rational modes of knowledge but also admits artisanal knowledge and the corresponding practices of epistemic authority. ${ }^{37}$

A photograph taken in her Beekman Street studio shows the artist amidst her woven forms that appear like a forest of beings and which were produced in resonance with her surroundings. 38 "They came into being while I did them," 39 recalls Tawney, wherein an animistic relationship to her works is evident that draws on Western metaphors, for example of breathing life into, as well as from Amerindian concepts. Tawney's dealings with the breathing body are not only manifest in the configuration of her figures. As opposed to her working method before her experiences with Sensory Awareness, her work turned into a process comparable with écriture automatique. The textiles were produced in a short and intense creative period between January and June 1962, about which

33 Tawney, cited from Jean d'Autilia 1978 (note 23), unpaged.

34 See Mona Schieren, "'Every Moment Is a Moment of Learning.' Lenore Tawney. New Bauhaus and Amerindian Impulses," in: Bauhaus Imaginista Journal, 2018, available at: http://www.bauhaus-imaginista.org/articles/2623/ every-moment-is-a-moment-of-learning (last accessed: 31.8.2020).

35 See Joyce S. Cheng, "Primitivisms," in: Neolithic Childhood. Art in a False Present, ca. 1930, exh. cat. Haus der Kulturen der Welt Berlin, Zurich/Berlin 2018, pp. 185-186.

36 Mona Schieren, "Transcultural Entanglements. Lenore Tawneys Fiber Art," in: Burcu Dogramaci (ed.), Textile Modernism, Cologne/Vienna 2019, pp. 411-424.

37 See De Sousa Santos 2019 (note 8), p. 43.

38 Tawney also names in this context the place where these works were produced as central: "These were done in the loft of South Street, a noble space. The interior width, length, height, the river had an atmosphere which disseminated over the work." Tawney, cited from Wilson (note 22), unpaged. For a critical examination of the photographs of Tawney in her studios and a consideration of the mythologized studio space, see Mona Schieren, "Raumkunst denken - Lenore Tawneys fiber art," in: Katharina Eck et al. (eds.), Wohn/Raum/Denken. Politiken des Häuslichen in Kunst, Architektur und visueller Kultur, Bielefeld 2021, pp. 83-101.

39 Tawney, cited from Munro 2000 (note 5), p. 330. T'ai Smith describes the "woven forms" as "ghostlike." See T'ai Smith, "Lenore Tawney. Asymmetries," in: Lenore Tawney. Wholly Unlooked For, exh. cat. Maryland Institute College of Art, Baltimore/University of the Arts, Philadelphia, Baltimore 2013, pp. 25-32, here: p. 25. 
she writes: "I did all that work in six months, working all the time, January until June. [...] They just poured out like a fountain or a river." ${ }^{40}$ She notes in her account that she did not have a preconceived plan when making these works; she solely drew the warp and then proceeded to weave intuitively: "[T]here was some kind of knowledge here in my center, and in my fingers, of proportions and everything else." ${ }^{\prime 1}$

This testifies to her experimental employment of the weaving apparatus during which the impulses of the weaver and her spontaneous breathing shape the rhythm of the process. This stands in stark contrast to the conventional weaving methods that are subject to a preplanned structure and led to the invention of mechanical, punch-card operated devices like the Jacquard loom in conjunction with industrialization and automatization..$^{42}$ When working with such devices, the weaver is only required to exert him- or herself physically; the body's breathing, by contrast, is completely subjected to the loom's predetermined mechanical rhythm. It is remarkable to note in this context that when Tawney became acquainted with the automated Jacquard weaving process in 1964, she did not see the artistic potential in the fabric or the technique but in the spatial arrangement of the "tie-up" ${ }^{43}$ of the thread strands. She found her new means of expression - again in close connection with her experience of Sensory Awareness - in the medium of drawing.

\section{Drawings since Monhegan, Summer 1964}

"These drawings on graph paper were done while I was studying a particular loom technique - on the Jacquard. I did them after coming back from Monhegan." ${ }^{44}$ They reveal in turn a connection to intense physical experiences Tawney achieved through the breathing practice - the workshop participants were known to the inhabitants of Monhegan Island as "the Breathers." One of the drawings is even titled "The Great Breath" (Fig. 4). The described experiments involving sensitizing oneself for one's own breath, thus making the connections within the organism tangible and flexible, can be related to the fine linear structures of the ink drawing on graph paper that are conducted through a so-called "funnel," as Tawney designated it. ${ }^{45}$ The coming and going of one's breath, led through the funnel of diaphragm and alternatingly expanding outwards can also be seen in the predominately red and

40 Tawney, cited from Munro 2000 (note 5), p. 330. 41 Ibd.

42 See fundamentally Birgit Schneider, Textiles Prozessieren. Eine Mediengeschichte der Lochkartenweberei, Zurich/Berlin 2007.
43 See Warren Seelig, "Thinking Lenore Tawney," in: exh. cat. Baltimore 2013 (note 39), p. 22. 44 Tawney, cited from Roche 1990 (note 6), p. 6. 45 Tawney, cited from Jean d'Autilia 1978 (note 23), unpaged. 


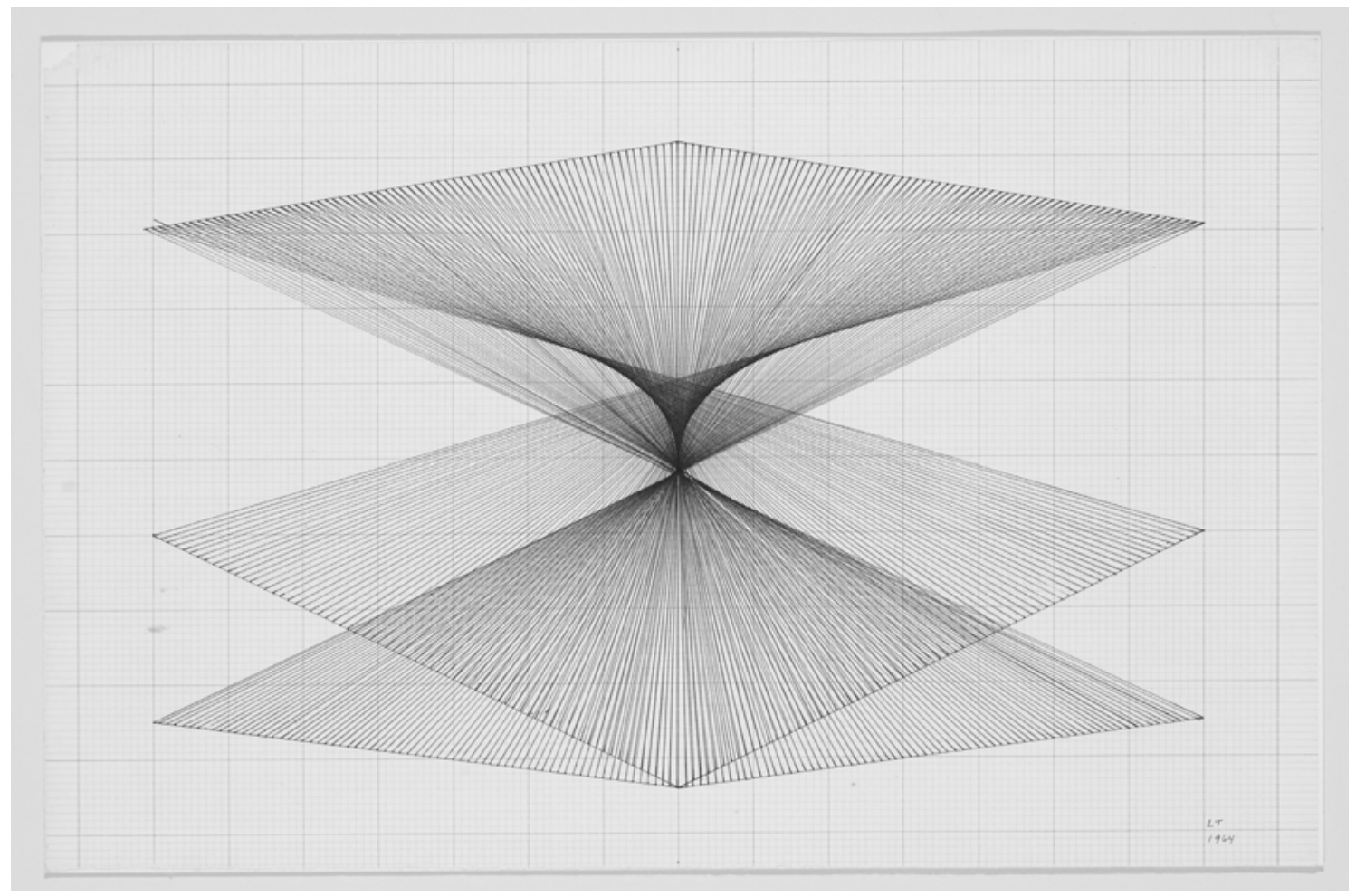

Fig. 4: Lenore Tawney, The Great Breath, India ink on graph paper, 1964, $28 \times 43 \mathrm{~cm}$ 

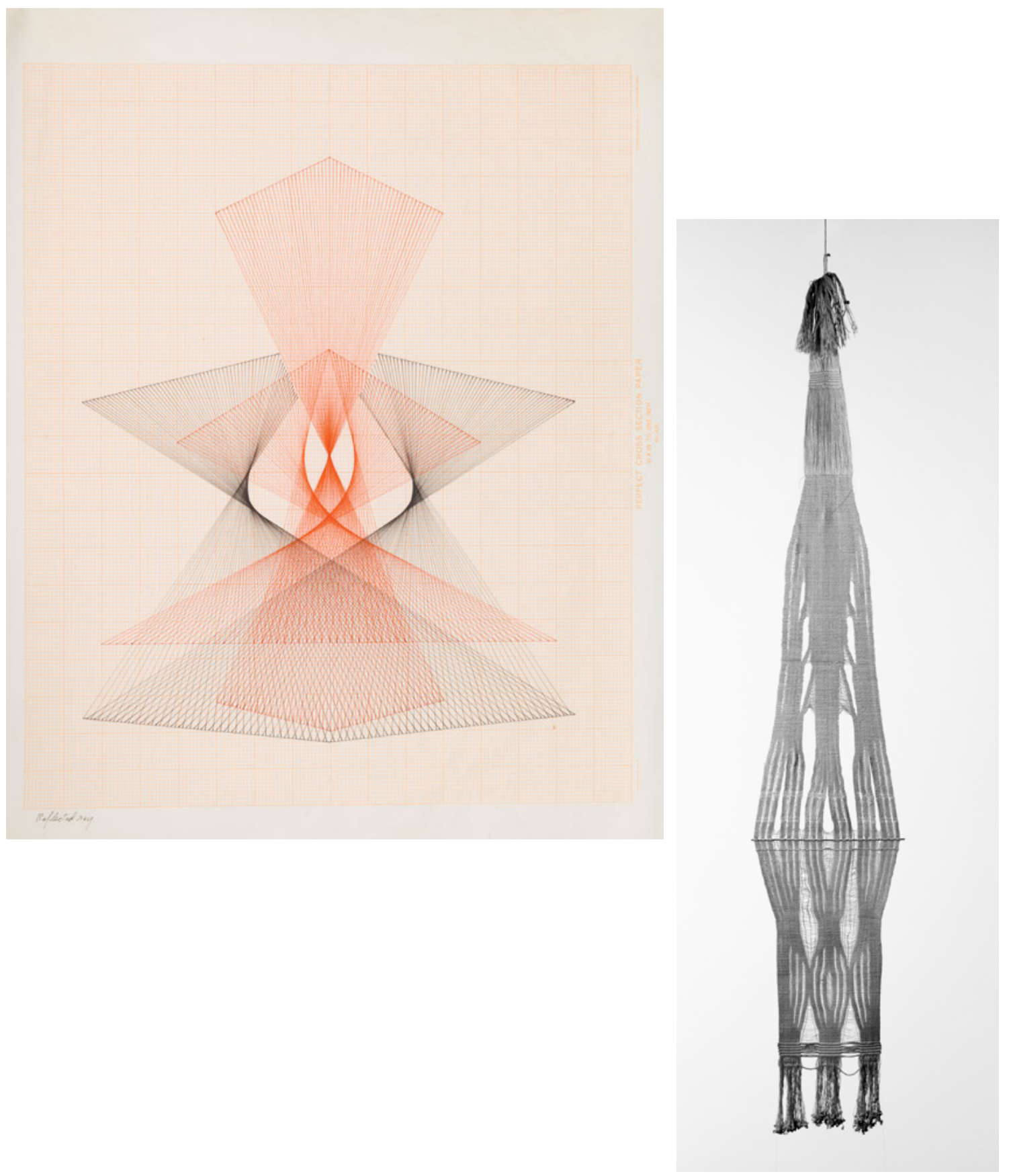
black 1964 drawing Reflected Ray (Fig. 5) from the same series. Fine layers of lines form a figure resembling the human body, symmetrical as far as possible from right to left, albeit not from top to bottom, and producing a shimmering moiré effect. The vertically arranged figuration recalls a human rib cage and pelvis area that successively expands through the breathing process; it stands, however, on a broad base against the backdrop of a linear triangle that widens towards the bottom - a further reminiscence of Selver's teachings to the extent that along with breathing, she named gravitation as the elementary force impacting the human being. The multilayered drawings are able to illustrate this pulsating breathing that even set the funnels in motion. The red lineal structures recall the flowing hara energy of the center of the body mentioned by Brooks that make the body tissue perceptible. ${ }^{46}$ That same year, 1964, Tawney produced the "woven form" with the title Breath of Earth (Fig. 6) in which the likewise pulsating, material-widening flows of air can be associated through the gauze weaving that widens towards the bottom through the force of gravity.

\section{Resonance - Somatic Relationships}

In a letter to Selver dated February 2, 1965, Tawney describes a now still unidentified weaving she made from black linen with white elements on the upper section for Selver's seminar; ${ }^{47}$ the artist wanted to bring it to Alan Watts' (house) boat on which Selver regularly taught. ${ }^{48}$ It can be assumed that Selver used Tawney's woven forms as illustrative material for her workshops insofar as the trained photographer often used photos of reed landscapes, for example, to visualize the bonds between the body and its surroundings. Based on Tawney's extensive description of the Peruvian gauze technique in which adjacent threads often loop each other multiple times, we can conjecture that she wanted to emphasize the ideas from Selver's classes she visualized pictorially. Breathing is the process in which the interior of body exchanges with the outside world. Just as Tawney's weavings span the space, connecting individual threads with each other by means of the gauze technique and entering into an exchange with the surroundings - through light, shadow and movement - Tawney's woven forms as well as the later post-1977 instal-

46 Brooks 1986 (note 13), p. 56.

47 Letter from Tawney to Selver, 22.2.1965, LGTF. It possibly concerns a weaving similar to Black Woven Form (Fountain) from 1966 which is comparable to The Fountain from 1963 (Fig. 3).
48 I am grateful to Stefan Laeng for information on Selver's teaching practice. 
lative complexes of works like the Cloud Series in the public space resonate with their surroundings.

\section{Conclusion}

Tawney experienced affixation physically through her work with Selver. Unlike comparable mind-body-spirit practices at the Weimar Bauhaus, for example, she did not intend this occupation with the body and breath as a means of producing the prerequisites for achieving a "betterment" of the artistic working process. ${ }^{49}$ The experiments serve, rather, the heightening of the perception of 'what is' and, like Zen, do not follow an explicit target orientation. It concerns the perception of breathing and to unlearn the learned disciplining conventions of the body, thus making it possible "that anxieties ease, inhibitions weaken." 50 Selver turns against making corrections and messing about with the world, stating that "in our explosive exploitation, we could perhaps make things worse." By unlearning societal and authoritarian manipulation, "we must recover our own capacity to taste for ourselves. Then we shall be able to judge also." ${ }^{11}$ With her experimental weaving processes, Tawney defies the disciplining conventions and standardized timings predetermined by industrial weaving machines. She produces textiles and drawings that can be read as pictorial embodiments of $\operatorname{cosmologies}^{52}$ in which the act of breathing unites the aesthetics of production and reception.

Translated from German by Michael Wolfson.

49 On Gertrud Grunow and Johannes Itten, see Linn Burchert, "Atem- und Pulsbilder. (Bio-)Rhythmisches Arbeiten am Bild," in: Christoph Büttner/Carolin Piotrowski (eds.), Im Rhythmus. Entwürfe alternativer Arbeitsweisen von 1900 bis in die Gegenwart, Paderborn 2018, pp. 59-76.

50 Brooks 1986 (note 13), p. 53.

51 lbd, p.7.
52 See in this regard Kathleen M. Ryor, "Guo Fengyi and the Embodied Cosmos," in: Drawing Papers 142 (=Guo Fengyi To See from a Distance), 14.2.2020, pp. 46-69. 